\title{
A new species of Porrbomma Simon, 1884 from the mountains of southern Siberia, Russia (Aranei: Linyphiidae: Linyphiinae)
}

\author{
Новый вид рода Porrbomma Simon, 1884 из гор Южной Сибири \\ (Россия) (Aranei: Linyphiidae: Linyphiinae)
}

\author{
Andrei V. Tanasevitch \\ A.B. Танасевич \\ Centre for Forest Ecology and Production, Russian Academy of Sciences, Profsoyuznaya Str. 84/32, Moscow 117997, Russia. E-mail: \\ tanasevitch@gmail.com \\ Центр по проблемам экологии и продуктивности лесов РАН, Профсоюзная ул. 84/32, Москва 117997, Россия.
}

KEY WORDS: spiders, Linyphiidae, Porrhomma, new species, mountains, southern Siberia, Russia.

КЛЮЧЕВЫЕ СЛОВА: пауки, Linyphiidae, Porrhomma, новый вид, горы южной Сибири, Россия.

\begin{abstract}
Porrhomma magnum sp.n. is described from the mountains of southern Siberia, Russia. The new species resembles $P$. longjiangensis Zhu et Wang, 1983 (sp. revalid.), but differs by certain details of genital structure, in the significantly larger size, pale body coloration, strongly reduced eyes, as well as by the chaetotaxy pattern. $P$. longjiangense is resurrected from the synonymy with $P$. rakanum Yaginuma et Saito, 1981, being also rediagnosed and accompanied by figures of the genitalia of both sexes.
\end{abstract}

РЕЗЮМЕ. Из гор Южной Сибири описан Porrhomma magnum sp.n., близкий к P. longjiangensis Zhu et Wang, 1983, но хорошо отличимый деталями строения гениталий обоих полов, а также бо́льшими размерами, светлой окраской и формулой хетотаксии. Вид P. longjiangensis (sp.rev.) восстановлен из синонимии с $P$. rakanum Yaginuma et Saito, 1981; приведены его новый диагноз и рисунки гениталий обоих полов.

\section{Introduction}

A new species of the linyphiid spider genus Porrhomma Simon, 1884 has been found in the mountainous of southern Siberia. The species is rather large, pale, with small, reduced eyes. It resembles $P$. longjiangensis Zhu et Wang, 1983, which is currently considered as a junior synonym of $P$. rakanum Yaginuma et Saito, 1981. P. longjiangensis was originally described from females from Heilongjiang Province, northeastern China [Zhu \& Wang, 1983] and later incorrectly synonymized with the Japanese cave-dwelling $P$. rakanum by Li \& Song [1993]. Marusik \& Koponen [2000] have noted that synonymy to be erroneous. I agree with that opinion and consider $P$. longjiangensis as a valid species (sp. revalid.), this being clear from the figures presented by Yaginuma \& Saito [1981] and
Eskov \& Marusik [1994], as well as those provided in the present paper.

\section{Material and methods}

This paper is based on the spider collections housed at the Zoological Museum of the Moscow State University, Moscow, Russia (ZMMU) and on the personal collection of Andrei Tanasevitch (CAT). Type specimens are shared between the collections of ZMMU and the Muséum d'histoire naturelle, Geneva, Switzerland (MHNG). Some more samples used here are also deposited in MHNG.

The sequence of leg segments in measurement data is as follows: femur + patella + tibia + metatarsus + tarsus. All measurements are given in $\mathrm{mm}$. Scale lines in figures correspond to $0.2 \mathrm{~mm}$.

The terminology of genitalic structures follows that of Wiehle [1956], but the term "conductor" is put here in quotation marks because it is widely used in various families to denominate the structure which functionally holds and protects the embolus, even though its homology is not confirmed.

Abbreviations used in the text and figures: AA anterior apophysis of embolic division, $\mathrm{Co}-$ "conductor", D - duct, DSA - distal suprategular apophysis, E - embolus, ED - entrance duct, Fe femur, MPE - membraneous part of embolus, TA tegular apophysis, Ti — tibia, TmI - position of trichobothrium on metatarsus I.

Results

\section{Porrhomma magnum sp.n.}

Figs 1-14, 23, 24.

HOLOTYPE O $0^{7}$ (ZMMU), KAZAKHSTAN, East Kazakhstan Area, Altai Mts, E of Lake Markakol, Tesnoy Spring, 2200 m a.s.l., 21.VI.1997, leg. R. Dudko \& V. Zinchenko. 


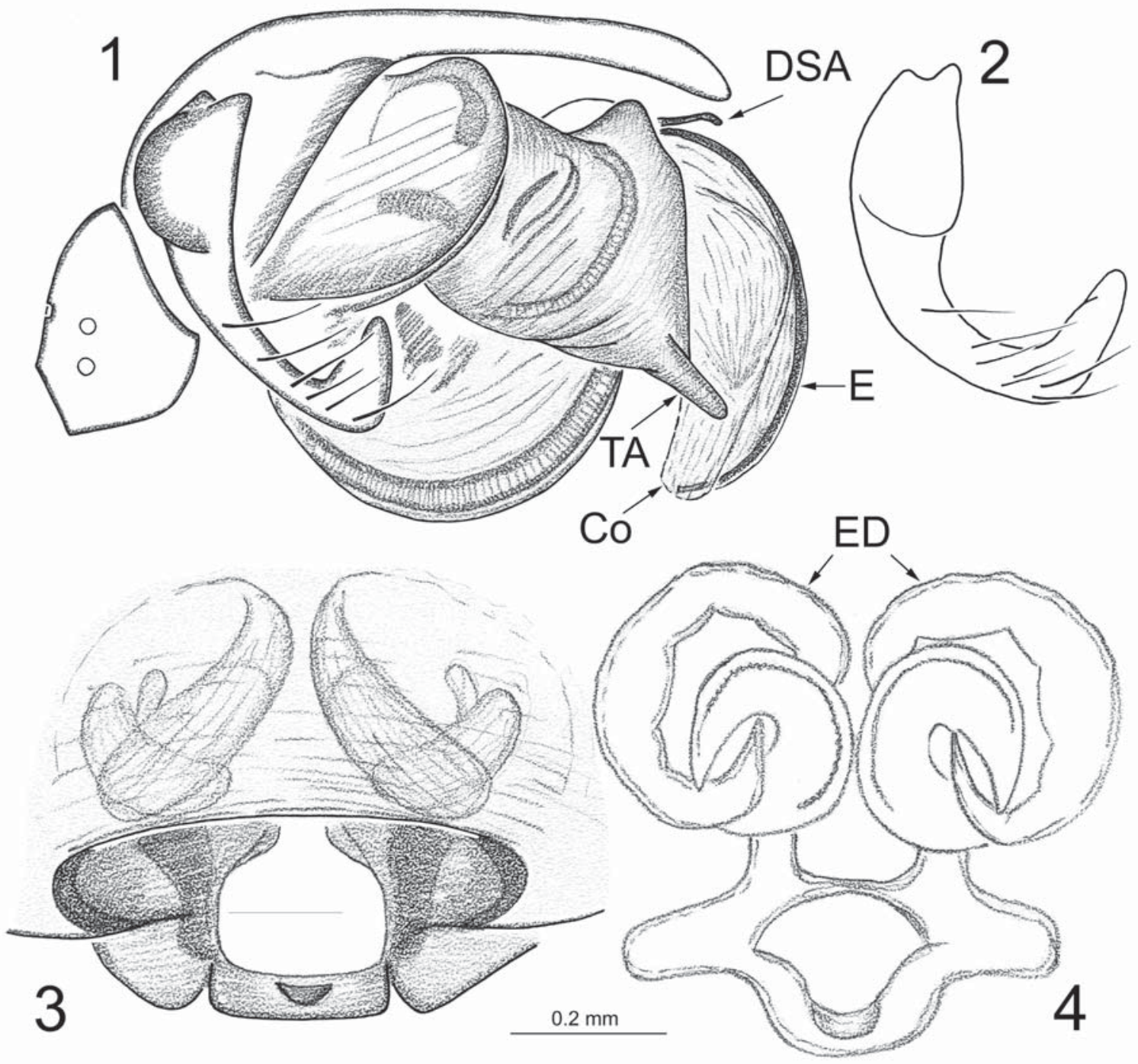

Figs 1-4. Palp and epigyne of Porrhomma magnum sp.n., holotype $(1,2)$, female paratype from Aradan $(3,4): 1$ - right palp, retrolateral view; 2 - paracymbium; 3, 4 - epigyne, ventral and dorsal views, respectively.

Рис. 1-4. Детали строения пальпы самца и эпигины Porrhomma magnum sp. n., голотип $(1,2)$, самка паратип из Арадана $(3,4)$ : 1 - правая пальпа, ретролатерально; 2 - парацимбиум; 3,4 - эпигина, соответственно вид снизу и сверху,

PARATYPES: 1 (ZMMU), same locality and date, together with holotype; 1 (ZMMU), RUSSIA, Republic of Khakassia, Abakanskiy Mt Ridge system, Choochek Mt Ridge, 20 km SSE of Mrassu Village, mountain stony tundra (= goltsy), 1600-1800 m a.s.1., 7-19.VII.1999, leg. D. Lomakin; 1 ऽ', 3 O+ (ZMMU, sub P. kulczynskii), 1 9 (MHNG), Krasnoyarsk Area, West Sayan Mts, 30-40 km S of Aradan Village, Oyskiy Mt Ridge, $1700 \mathrm{~m}$ a.s.1., mountain tundra with moss \& dwarf shrubs, 8.VII.1993, leg. D Logunov.

NAME. To emphasize the large size.

DESCRIPTION. Male (holotype). Total length 3.35. Carapace 1.55 long, 1.00 wide, pale brown. Eyes present, but very small, strongly reduced, without or with poorly expressed black rings around. Clypeus, face and occiput with sparse, long, thin hairs. Chelicerae 0.80 long, brown, unmodified. Legs pale yellow. Leg I, 5.50 long $(1.45+0.45+1.40+1.30+0.90)$, IV, 5.40 long $(1.45+0.35+1.40+1.35+0.85)$. Chaetotaxy. FeI: 1(2)-2-0-0, II-IV: 1-0-0-0; TiI: 2-1-1-0, II: 2-0-10 , III-IV: 2-0-0-0; metatarsi spineless. TmI, 0.37. Palp (Figs 1, 2, 9-11, 23): Paracymbium with a swollen proximal part, as well as a narrow, long, L-shaped, distal part bearing a few short spines. Distal suprategular apophysis a fishing hook with a long stock. Anterior apophysis of embolic division (= "Vordere Apophyse" of "Embolusteil" sensu Wiehle [1956: fig. 375] = anterior apophysis of "lamella" sensu Merrett [1963]) very short, hook-shaped; posterior apophysis (= "Hinter Apophyse" sensu Wiehle [1956]) absent. Embolus with a wide membraneous part, the latter with a well visible sperm duct inside. "Conductor" transparent, wide, accompanying embolus all along. Abdomen 1.75 long, 1.10 wide, white. 

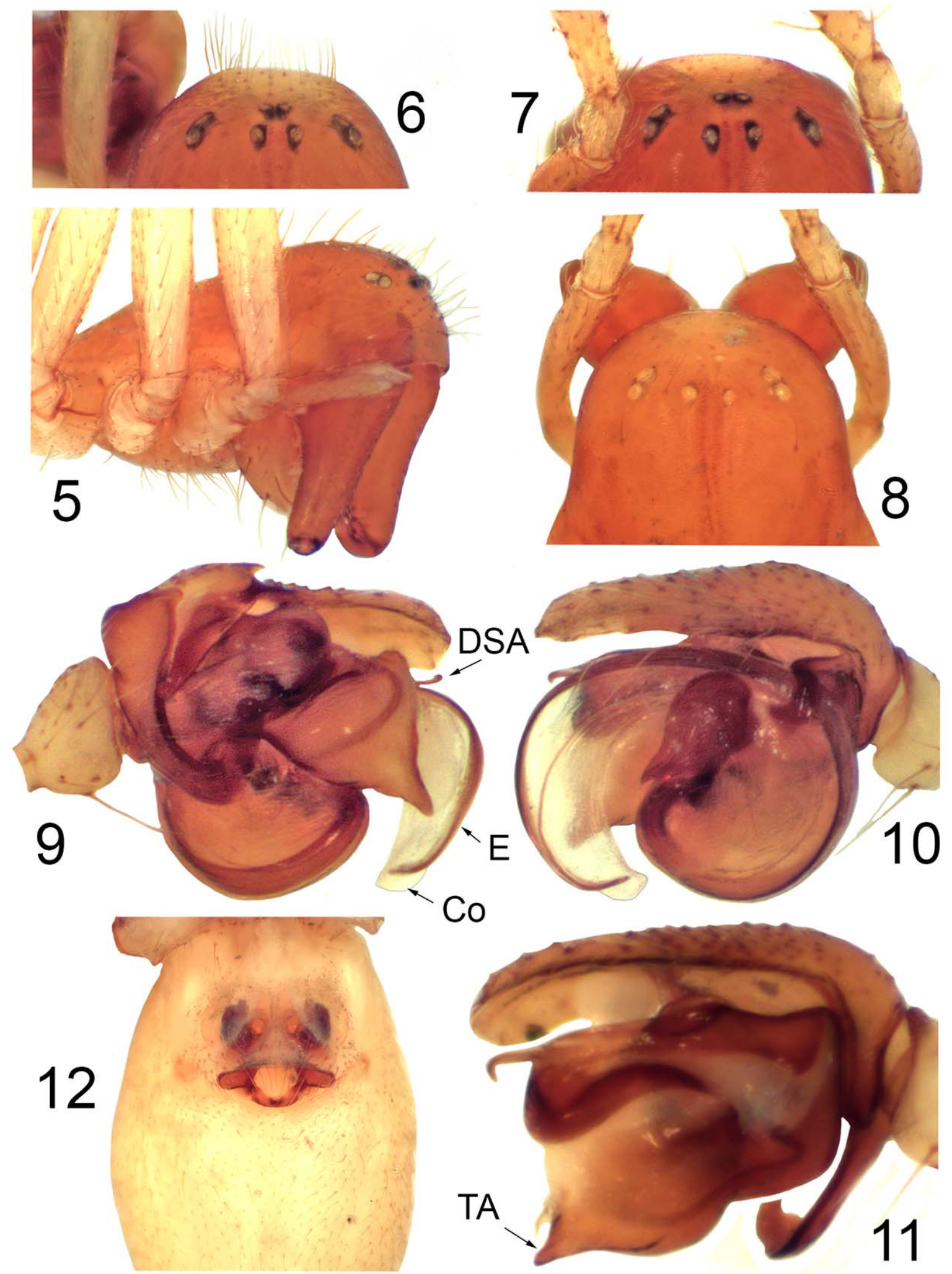

Figs 5-12. Porrhomma magnum sp.n., holotype (5), a male and female paratypes from Aradan (6-12): 5, 6 - head part of male carapace; 7, 8 - head part of female carapace; 9, 10 - right palp, retrolateral and prolateral views, respectively; 11 - palp without embolic division; 12 - female abdomen, ventral view.

Рис. 5-12. Porrhomma magnum sp.n., самец голотип (5), самец и самки паратипы из Арадана (6-12): 5, 6 - головной отдел карапакса самца; 7, 8- головной отдел карапакса самки; 9,10 - правая пальпа, соответственно ретролатерально и пролатерально; 11 - пальпа без эмболюсного отдела; 12 - абдомен самки, вид снизу. 


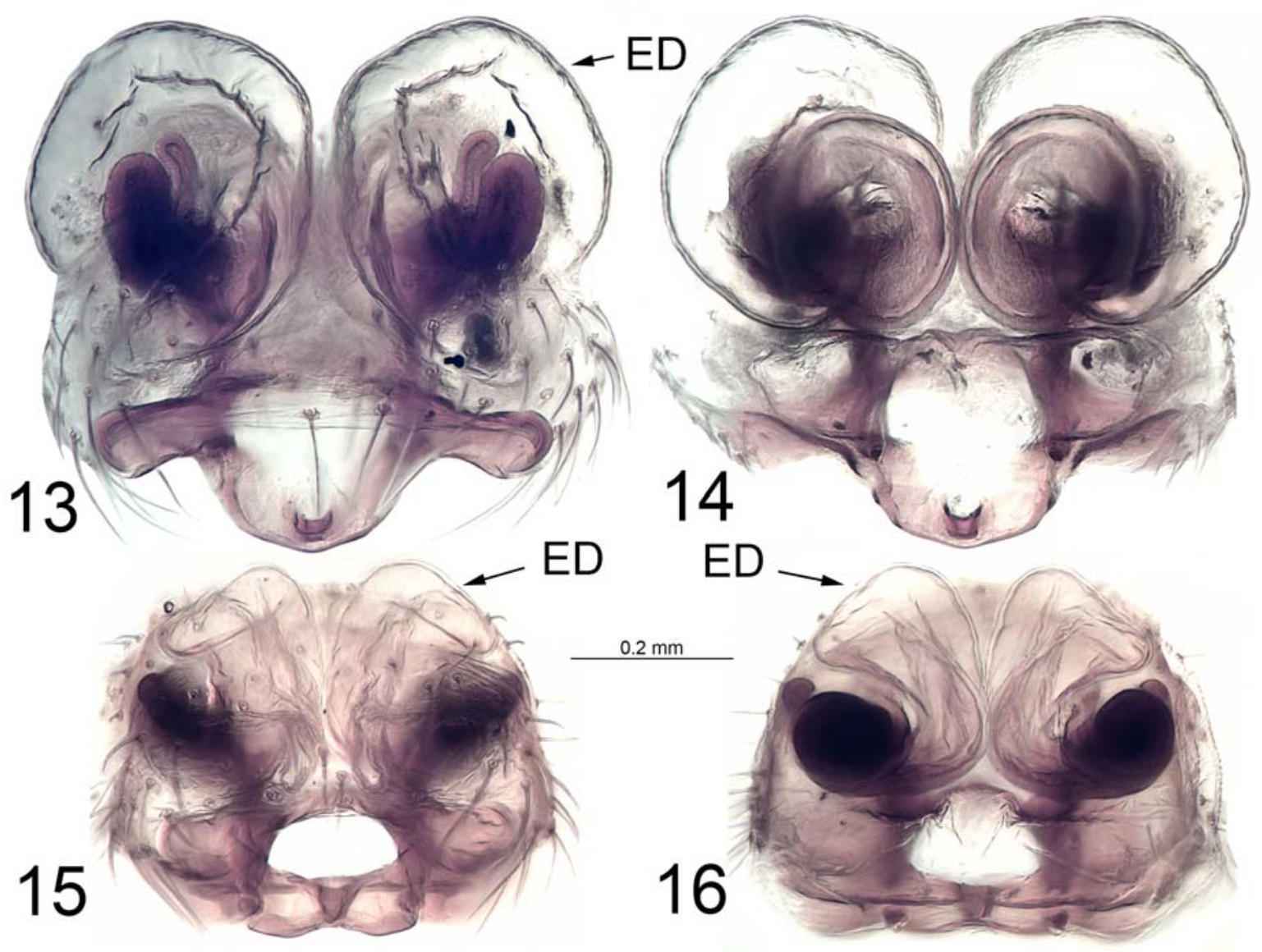

Figs 13-16. Vulva of Porrhomma magnum sp.n. (13, 14), paratype from Aradan, and P. longjiangensis Zhu et Wang, 1983 from Norskiy Nature Reserve $(15,16): 13,15$ - ventral view; 14, 16 - dorsal view.

Рис. 13-16. Эндогина Porrhomma magnum sp.n. (13, 14), паратип из Арадана, и P. longjiangensis Zhu et Wang, 1983 из Норского заповедника $(15,16): 13,15$ - вид снизу; 14,16 - вид сверху.

Female (from Lake Markakol). Total length 3.70. Carapace 1.65 long, 1.35 wide, head almost bare. Chelicerae 0.80 long, unmodified. Leg I, 6.10 long $(1.75+0.45+1.55+1.50+0.85)$, IV, 6.15 long $(1.75$ $+0.35+1.60+1.55+0.90)$. Chaetotaxy. FeI: 1(3)-20-0, II: 1(2)-0-0-0, III-IV: 1-0-0-0; TiI: 2-1-1-0, II: 20-1-0, III-IV: 2-0-0-0; metatarsi spineless. TmI, 0.34. Abdomen 2.25 long, 1.35 wide. Body and leg coloration, size of eyes as in male. Epigyne (Figs 3, 4, 12-14) with wide, everted, lateral walls. Entrance ducts very long, wide, describing a loop, receptacles bean-shaped in ventral view.

VARIABILITY. Total length vary in males from 2.80 to 3.35 , in females from 3.34 to 3.75 , specimens from the West Sayan are slightly darker, but anyway generally very pale.

TAXONOMIC REMARKS. The new species strongly resembles $P$. longjiangense Zhu et Wang, 1983, known from the Russian Far East and northeastern China, but is well distinguished by certain details of genital structure in both sexes, as well as by the significantly larger size, pale body coloration, strongly re- duced eyes, coupled with the shape of the entrance ducts and the chaetotaxy pattern: in $P$. longjiangense femora II-IV are unarmed, while in P. magnum sp.n. femora II-IV each bears a dorsal spine.

Porrhomma longjiangensis Zhu et Wang, 1983, sp. revalid.

Figs 15-22.

1983 Porrhomma longjiangensis Zhu \& Wang: 148, figs a-e, ㅇ. 1986 P. longjiangensis. - Zhu, Wen \& Sun: 207, 3a-b, o7.

1994 P. longjiangensis. - Eskov \& Marusik: 52, figs 45-48, $\sigma^{7} \&$ \&

MATERIAL EXAMINED. $5 \sigma^{\top} \sigma^{\top}, 6$ o 6 (ZMMU, sub Porrhomma sp.), RUSSIA, Magadan Area, upper reaches of Kolyma River, environs of Seimchan, 2-4.IX.1990, leg. Y. Marusik; 1 ऽ, 6 우 (ZMMU, sub Porrhomma sp.), Magadan City, bank of Magadanka River, under stones, 23.VIII.-1.IX.1987, leg. Y. Marusik; 2 +o (ZMMU, here and below sub P. longjiangensis), RUSSIA, Khabarovsk Area, $240 \mathrm{~km}$ from Khabarovsk, Amur River flow, Rybachiy Island, 18.VI.1988, leg. D. Kurenshchikov; $1 \sigma^{7}, 1$ q (ZMMU), near Achan, 27.V.1989, leg. D. Kurenshchikov; $1 \sigma^{\top}$, 2 우 (ZMMU), near Malmyzh, 23.VIII.1987, leg. N. Ryabinin; 1 ơ, 1 \& (ZMMU), Bolshekhekhtsyrskiy Nature Reserve, VI.1987, leg. D. Logunov; 1 (CAT), Verkhnebureinskiy Distr., Bureinskiy 

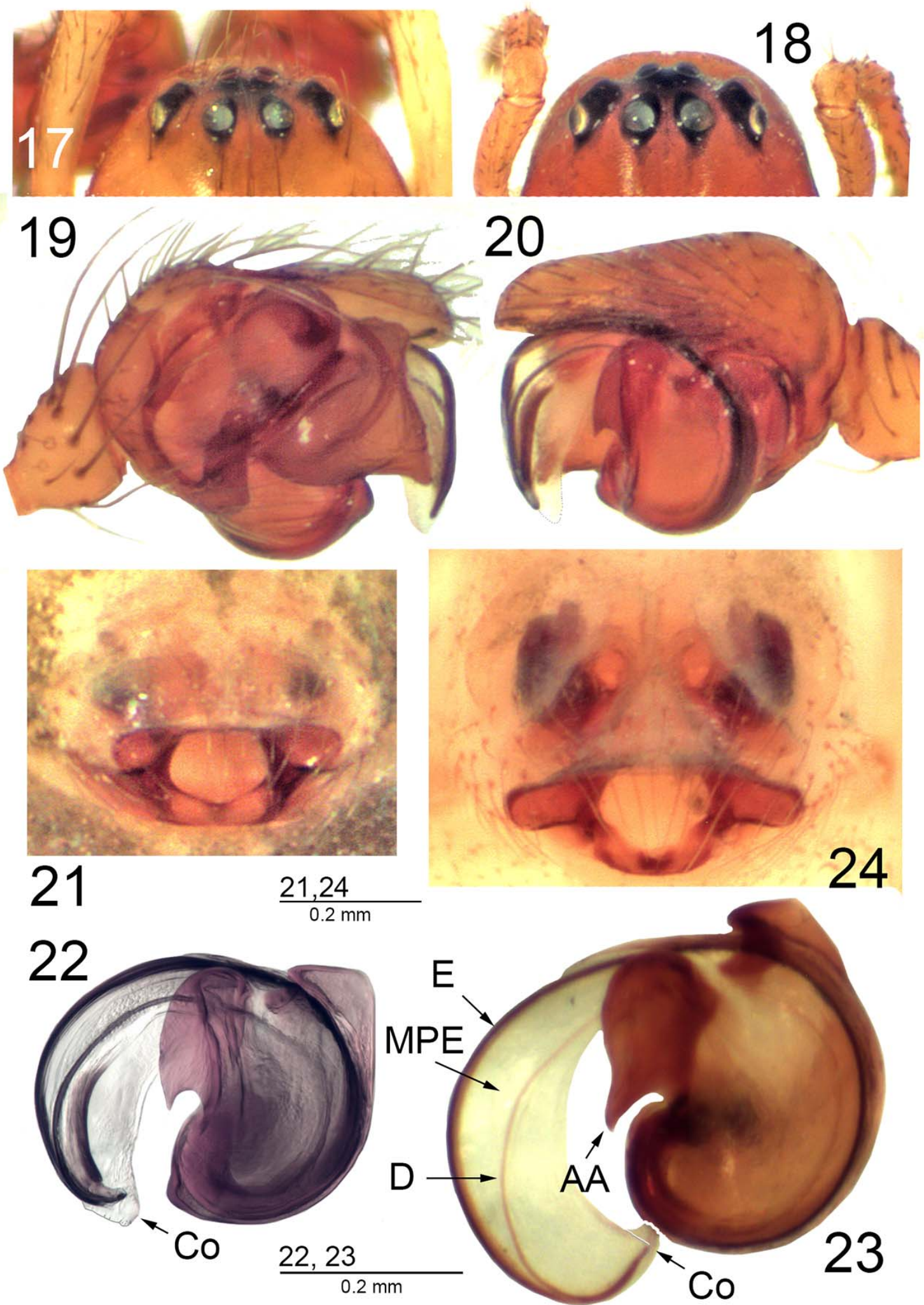

Figs 17-24. Porrhomma longjiangensis Zhu et Wang, 1983 (17-22) from Semeldzha, and P. magnum sp.n. (23, 24), paratypes from Aradan: 17, 18 - head part of male and female carapace, respectively; 19, 20 - right palp, retrolateral and prolateral, respectively; 21, 24 - epigyne, ventral view; 22, 23 - embolic division.

Рис. 17-24. Porrhomma longjiangensis Zhu et Wang, 1983 (17-22) из Семельджи, и P. magnum sp.n. (23, 24), паратипы из Арадана: 17,18 - соответственно головной отдел карапакса самца и самки; 19,20 - правая пальпа, соответственно ретролатерально и пролатерально; 21, 24 - эпигина, вид снизу; 22, 23 - эмболюсный отдел. 
Nature Reserve, near Cordon Strelka, 22.IX.2006, leg. A. Ryvkin; $1 \sigma^{7}$ (CAT), $1 \sigma^{7}, 1$ \& (ZMMU), Arkhara Distr., Khinganskiy Nature Reserve, VIII.1999, leg. unknown; $10^{7}, 5$ ○ᄋ (CAT), Amu Area, Selemdzhinskiy Distr., near border to Norskiy Nature Reserve, island on Selemdzha River near Cordon Dvadtsatikha, leaf litter, 6.VIII.2004, leg. A. Ryvkin; 3 o $^{7} \sigma^{7}, 2$ 우 (ZMMU), $10^{7}, 2$ 우 (MHNG), Mazanovskiy Distr., Nora River mouth, 205 m a.s.1., mosses \& leaf litter by side of a small flood-plain lake, 4.VIII.2006, leg. E. Veselova \& A. Ryvkin; 1 (ZMMU), Selemdzhinskiy Distr., Norskiy Nature Reserve, Nora River, near Cordon Maltsevskiy, mosses and leaf litter under Salix, Alnus, Padus near lake, 3.IX.2004, leg. A. Ryvkin; $3 O^{7} O^{7}, 2$ 우 (CAT), Mazanovskiy Distr., Nora River mouth, plant debris, mosses \& leaf litter, 4 6.VIII.2006, leg. E. Veselova \& A. Ryvkin; $1 \sigma^{7}, 1$ q (CAT), Maritime Prov., $35 \mathrm{~km}$ SE of Chyuguevka, Verkhneussuriyskiy Field Station, pile of logs, 11.VII.1990, leg. A. Tanasevitch; $1 O^{7}, 1$ \& (CAT), Ussuri Distr., Gornotayozhnoye Village, garbage, 919.VII.1990, leg. A. Tanasevitch; $1 \mathrm{O}^{7}, 1$ ㅇ (ZMMU), Kedrovaya Pad' Nature Reserve, Kedrovaya River, $0.5-1 \mathrm{~km}$ upstream of the reserve's central office, 8.X.2008, leg. D. Osipov.

DIAGNOSIS. The species is similar both to Porrhomma magnum sp.n. (see above) and the Japanese cave-dwelling $P$. rakanum. From the latter, the new species differs by the absence of a long conical tegular apophysis, by the much longer embolus, by the smaller and narrower paracymbium, as well as by the shape of the entrance ducts and receptacles.

SHORT DESCRIPTION. Total length of males 2.20-2.60, females, 2.30-2.60 (3.50 in the original description?!). Carapace yellow-red to dark reddish brown. Eyes normal, with black rings around. Head devoid of sparse, long, thin hairs, almost bare. Chelicerae unmodified. Legs yellow to pale brown. Chaetotaxy. FeI: 1-1-0-0, II: 1(0)-0-0-0; III-IV: 0-0-0-0; TiI: 2-1-1-0, II: 2-0-1-0, III-IV: 2-0-0-0. TmI, 0.25-0.28 in males, $0.25-0.29$ in females. Abdomen dark gray to black. Genitalia as in Figs 15, 16, 17-22.
DISTRIBUTION. The Russian Far East from the Magadan Area southward to the southern part of the Maritime Province; Jilin and Heilongjiang provinces, China.

ACKNOWLEDGEMENTS. I am deeply obliged to Dr Kirill Mikhailov (Moscow, Russia) for the possibility to work with the ZMMU collection. All the collectors whose material has been used in this paper are cordially thanked. Special thanks go to Dr Sergei Golovatch (Moscow, Russia) who kindly checked the English of an advanced draft.

\section{References}

Marusik Y.M., Koponen S. 2000. New data on spiders (Aranei) from the Maritime Province, Russian Far East // Arthropoda Selecta. Vol.9. No.1. P.55-68.

Zhu C.D., Wang H. 1983. [A new species of spider of the genus Porrhomma (Araneae: Linyphiidae)] // J. Norman Bethune Med. Univ. Vol.9 (Suppl.). P.148-149 [in Japanese, with English summary].

Yaginuma T., Saito H. 1981. A new cave spider of the genus Porrhomma (Araneae, Linyphiidae) found in a limestone cave of Shikoku, southwest Japan // J. Speleol. Soc. Japan. Vol.6. P.33-36.

Li S. Q., Song D.X. 1993. On the diagnostic characters of linyphiid spiders, with descriptions of some species (Araneae: Linyphiidae) // Sci. Treatise Syst. Evol. Zool. Vol.2. P.247256.

Eskov K.Y., Marusik Y.M. 1994. New data on the taxonomy and faunistics of North Asian linyphiid spiders (Aranei Linyphiidae) // Arthropoda Selecta. Vol.2. No.4. P.41-79.

Zhu C.D., Wen Z.G., Sun X.J. 1986. Description of two new species and the male spider of one species of Linyphiidae (Arachnida: Araneae) // J. Norman Bethune Univ. Med. Sci. Vol.12. P.205-208.

Responsible editor K.G. Mikhailov 